\title{
THE INFLUENCE OF ANIME ON THE EXISTENCE OF INDONESIAN LANGUAGE AND LITERATURE
}

\author{
Anindra Candrika Santiana ${ }^{1}$, Moses Glorino Rumambo Padin ${ }^{2}$, Vitor Ilham Mukadiª \\ Ahza Naufal Badiuzdzakwan ${ }^{4}$ \\ 1, 2,3,4 Departemen Bahasa dan Sastra Inggris, Universitas Airlangga \\ Jl. Airlangga No. 4-6, Airlangga, Kec. Gubeng, Kota Surabaya, Jawa Timur 60115 \\ ${ }^{1}$ Email: anin.candrika.santiana-2020@ fib.unair.ac.id \\ ${ }^{2}$ Email: moses.glorino@ fib.unair.ac.id \\ ${ }^{3}$ Email: vitor.ilham.mukadi-2020@ fib.unair.ac.id \\ ${ }^{4}$ Email: ahza.naufal.badiuzdzakwan-2020@ fib.unair.ac.id
}

\begin{abstract}
The form of literary works is increasingly varied over time. In the past, one can only share their thoughts in oral form, but now, they can express their idea, thoughts, and work through visual media. One example is anime. Anime is becoming more popular among Indonesian, especially students. This article focused on anime's influence on students' motivation to study the Japanese language and its effects on the Indonesian language and literature existence. Questions that arise from this topic are how anime influences students' motivation to study the Japanese language and literature, its relevance on the Indonesian language and literature existence, the effect of watching anime, and how to deal with the negative effects that might occur. This research uses an interactive qualitative method with surveys and interviews to collect the data. The data obtained were analyzed descriptively and presented in tables. The results of the research indicate that anime is indeed influencing students' interest to study the Japanese language and literature which can affect the Indonesian language and literature existence, there are negative effects of watching anime, and efforts need to be done to prevent and overcome these negative impacts. Due to the pandemic, the data collection process was carried out online via Google Forms and WhatsApp. Therefore, the data obtained is not as good as the data collected face-to-face.
\end{abstract}

Keywords: language, literature, anime, Japan

\section{INTRODUCTION}

In this globalization era, the development of technology is growing rapidly. This is what we called the digital era. Digital technology that is increasingly widespread also has an impact on aspects of literary works. With the easier dissemination of information, the publication of literary works has become easier.

Expressions of the human heart in the form of experiences, thoughts, feelings, ideas, enthusiasm, and beliefs in the form of life illustrations as outlined in writing using language tools are the meaning of literary works based on Sumardjo and Saini (2014). In other words, literature is a medium for delivering ideas or thoughts of someone to someone else using language as an intermediary. Literature is evolving. The form of literary works also become more varied. 
In the past, one can only share their thoughts in oral form, but now, they can express their idea, thoughts, and work through visual media. Literary works can be enjoyed more lively as a film. A film is the projection of images in a frame through a projector lens mechanically so that those images look alive (Arsyad, 2014). Mario Klarer once said in his book, An Introduction to Literary Studies (1998), that film is part of literary work. There are so many genres and types of film, and one of the well-known types of film is anime.

Bahtiar (2021) stated that the word anime comes from the Japanese language which means animation in English, whereas in Indonesian it becomes animasi. Anime (アニメ; a-ni-me) is a Japanese film or animation that has characteristics of colorful images, as well as various characters, locations, and stories. Anime shows various Japanese cultures and uses the Japanese language in the dialogue.

Meanwhile, according to Slameto (2011), interest is a constant tendency to pay attention and remember some activities. An activity that a person is interested in and carried out continuously with a happy feeling.

Students' interest in doing something like learning new things is based on motivation. Motivation itself is an encouragement for someone to learn something in order to realize a goal, said Dariyo (2004). If a person clearly knows the goals or ideals he wants to achieve in the future, he will have a strong motivation to pursue them.

Just like learning a language, motivation plays a big role in it. Rahman (2018) said that motivation is the most important aspect of learning a language as seen from the perspective of social psychology. People who have strong motivation might have a bigger chance of successfully achieving their goals.

In this study, the authors wanted to find out whether after the students watched anime, the anime could be a motivation for students to study the Japanese language and literature, and then analyze its effect on the students' interest in using the Indonesian language and reading Indonesian literature itself. To find this out, the writer tries to do a study that focuses on English language and literature students who like to watch anime and have an interest in studying Japanese language and literature, or in other words, students outside the Japanese language and literature study program itself. Moreover, in their daily life, those students are very attached to the use of English, such as carrying out lectures, doing assignments, and also studying lecture material.

The increasing popularity of anime that has become a trend among Indonesian teenagers today and English language and literature students' strong interest in Japanese cross-major courses make the writer 
interested in investigating whether these two things are related. The authors want to know the relationship between watching anime and students' interest and motivation in studying Japanese, as well as their interest in exploring Japanese literature. To figure this out, the authors try to conduct a case study on English language and literature students at Airlangga University who have an interest in watching anime and studying Japanese language and literature.

There is a theory and research that had been done regarding interest and motivation in studying the Japanese language, literature, and culture. The theory put forward by Toyoshima (2013) regarding the "virtuous cycle" is describing the relationship between Japanese language learning and the consumption of popular culture (anime, manga, and others). Toyoshima stated that:

“...when a student becomes interested in manga, the interest will be a motivation to learn the Japanese language. After the student starts to learn Japanese, he or she may become interested in J-pop, which may motivate the student to learn the language with even greater enthusiasm. Later, as the student's language ability improves, the student may in turn become interested in Japanese dramas and movies. The encounters with new Japanese cultural products become motivators for the student to continue learning the language, and they also enhance the student's interest in Japan and its culture".

Based on this theory, students who may initially only be interested in manga, or other versions of anime, after mastering Japanese or after their abilities increase, their interest in other Japanese cultural products will emerge and increase their motivation or desire to learn Japanese. Even a person who is studying Japanese and initially has no interest in Japanese popular culture is more likely to become interested in the product after mastering the Japanese language to a certain degree. The same thing may also happen among English language and literature students who are studying Japanese at Airlangga University.

Next, the study conducted by Rahmah (2019) revealed that the results of a survey taken from 70 respondents who were students of Indonesian language and literature at Diponegoro University who took Japanese as a cross-major course in the 2016/2017 academic year, as many as $79 \%$ admitted that their interest in Japanese learning comes from the element of fun, and most of the answers stated that the fun comes from manga and anime. Moreover, integrative motivation also has an influence on the choice of respondents as much as $60 \%$ in learning Japanese, most of the answers said that the motivation that arises is due to the attraction of Japanese culture and art. This shows that anime is indeed a source of motivation for students of Indonesian language and literature at Diponegoro University in studying the Japanese language and literature. 
It can be concluded from the theory and research that there is a relationship between anime and students' motivation in studying the Japanese language, literature, and even culture. Researches about the benefits and effects of anime on students' desire to learn Japanese have been carried out. However, as far as the search that has been done by the authors, there has been no research on how anime influences students' motivation to learn the Japanese language and literature toward the existence of the Indonesian language and literature itself. How do anime influence students' motivation to study the Japanese language and literature? Then, what does this have to do with the existence of the Indonesian language and literature? Can anime have a positive effect on students or vice versa? How to overcome the negative effects that affect the existence of the Indonesian language and literary works that may be caused by anime?

In this study, the authors aim to reveal how the students think about anime, the relationship between studying Japanese language and literature on the existence of Indonesian language and literature, and to remind the urgency of preserving Indonesian language and culture among students, especially undergraduate students of English Language and Literature at Airlangga University. The rapid development of the digital era and the widespread trend of watching anime are expected to have a positive impact on students. For this reason, it is necessary to make efforts that can support the preservation of the Indonesian language and culture.

\section{METHOD}

The method used in this research is interactive qualitative. Using this method, the authors hope to obtain results that are more specific and less general. Data collection techniques used are questionnaires and interviews. The focus of this research is the third-semester English department students of Airlangga University 2021/2022 academic year. The questionnaire ended with data obtained from 30 respondents. The authors assume that if students of English language and literature master many languages (Indonesian, English, and Japanese), then this will affect their interest in the Indonesian language and literary works. By using questionnaires, it is hoped that the authors can collect data quickly with easy-to-direct questions so that the closed-form questionnaire could increase the validity and reliability of the data. To complete the data that had been obtained from the respondents, further data collection was carried out through interviews. Then, using the descriptive analysis technique, the authors will analyze the respondents' answers and present them using descriptive tables.

Table 1. Interactive qualitative research using the descriptive analysis method steps

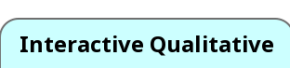

Research
Collecting data through questionnaires and interviews
Analyze data descriptively
Present the results in tables
Problem discussion Conclusion 


\section{RESULTS}

Table 2. Questionnaire results

\begin{tabular}{|c|c|c|c|c|}
\hline & Context & Question & Option & $\begin{array}{l}\text { Percentage } \\
\text { (frequency) }\end{array}$ \\
\hline \multirow{2}{*}{1} & \multirow{4}{*}{$\begin{array}{l}\text { Students' interest in learning the } \\
\text { language and culture of anime. }\end{array}$} & \multirow{4}{*}{$\begin{array}{c}\text { After watching anime, would you } \\
\text { like to learn its language and } \\
\text { culture? }\end{array}$} & Yes & $40 \%(12)$ \\
\hline & & & Probably & $46.7 \%(14)$ \\
\hline & & & Haven't decided yet & $10 \%(3)$ \\
\hline & & & No & $3.3 \%(1)$ \\
\hline \multirow{4}{*}{2} & \multirow{4}{*}{$\begin{array}{l}\text { Students' interest in exploring } \\
\text { other Japanese literary works }\end{array}$} & \multirow{4}{*}{$\begin{array}{l}\text { Are you getting interested in } \\
\text { exploring other Japanese } \\
\text { literary works besides anime? } \\
\quad \text { (songs, poems, etc.) }\end{array}$} & Interested & $53.3 \%(16)$ \\
\hline & & & Not really & $16.7 \%(5)$ \\
\hline & & & $\begin{array}{l}\text { Not interested but } \\
\text { can enjoy it }\end{array}$ & $23.3 \%(7)$ \\
\hline & & & Not interested at all & $6.7 \%(2)$ \\
\hline \multirow{3}{*}{3} & \multirow{3}{*}{$\begin{array}{c}\text { Students response regarding the } \\
\text { influence of anime on students' } \\
\text { interest in reading/preserving } \\
\text { Indonesian language and literary } \\
\text { works }\end{array}$} & \multirow{3}{*}{$\begin{array}{l}\text { Does anime affect students' } \\
\text { interest in the Indonesian } \\
\text { language and literature? }\end{array}$} & Yes & $60 \%(18)$ \\
\hline & & & Not really & $26,7 \%(8)$ \\
\hline & & & No & $13.3 \%(4)$ \\
\hline
\end{tabular}


Table 3. Interview results

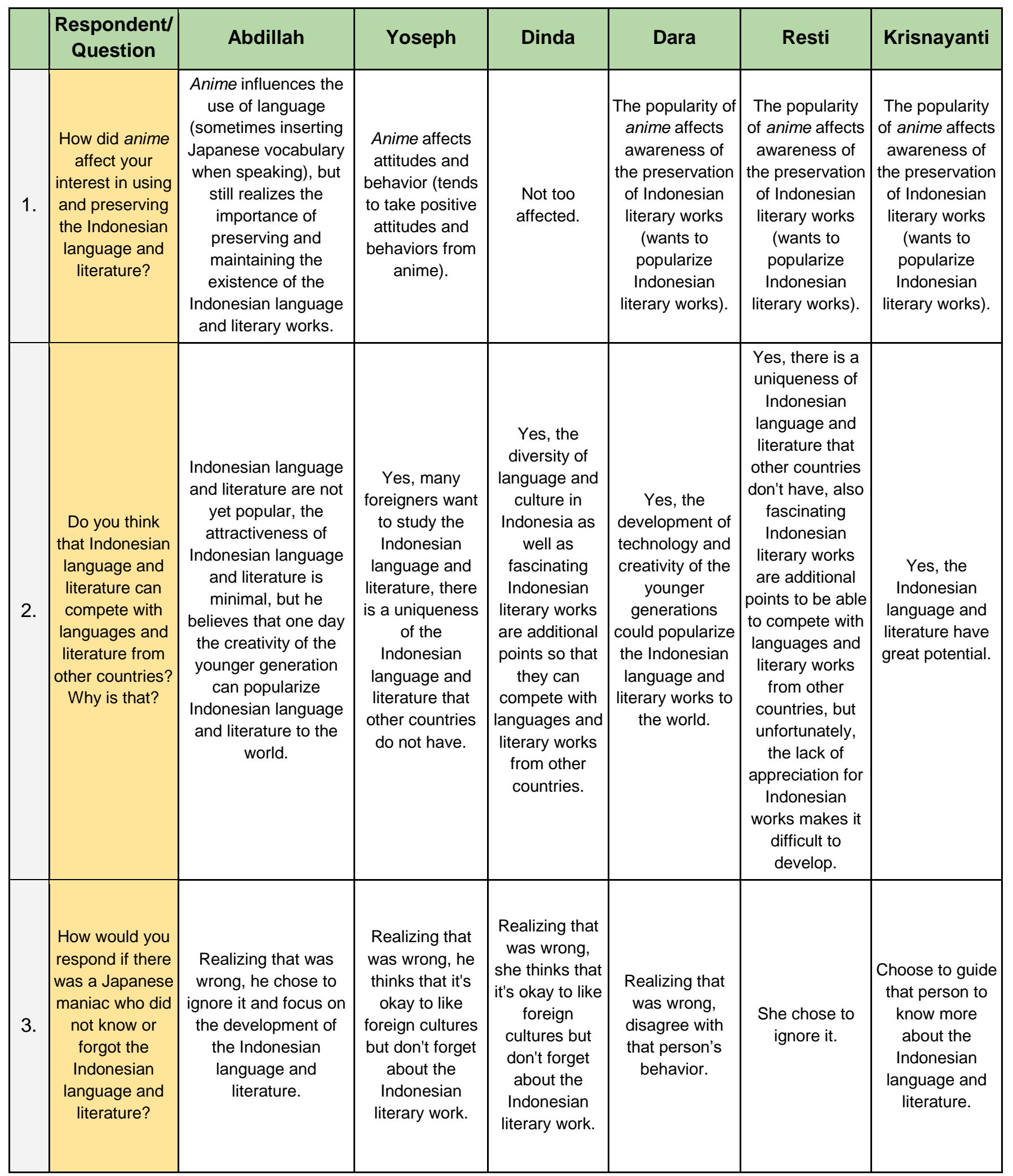




\begin{tabular}{|c|c|c|c|c|c|c|c|}
\hline 4. & $\begin{array}{c}\text { What will } \\
\text { happen if the } \\
\text { Indonesian } \\
\text { language and } \\
\text { literature are } \\
\text { continuously } \\
\text { forgotten by } \\
\text { other countries' } \\
\text { languages and } \\
\text { literature? }\end{array}$ & $\begin{array}{c}\text { Indonesia will not be } \\
\text { able to become a } \\
\text { developed country, } \\
\text { the Indonesian } \\
\text { language and literary } \\
\text { works will be forgotten } \\
\text { and disappear sooner } \\
\text { or later. }\end{array}$ & $\begin{array}{l}\text { The Indonesian } \\
\text { can lose its } \\
\text { national identity. }\end{array}$ & $\begin{array}{c}\text { Indonesian } \\
\text { language and } \\
\text { literature will } \\
\text { be forgotten } \\
\text { and disappear } \\
\text { sooner or later. }\end{array}$ & $\begin{array}{c}\text { The people's } \\
\text { ability to use the } \\
\text { Indonesian } \\
\text { language will } \\
\text { decrease, many } \\
\text { Indonesian } \\
\text { literary works } \\
\text { will be taken } \\
\text { over } \\
\text { (recognized) by } \\
\text { other countries. }\end{array}$ & \begin{tabular}{|} 
The Indonesian \\
can lose its \\
national identity, \\
Indonesian \\
literary works \\
will be filled with \\
other languages \\
because the \\
people \\
themselves do \\
not understand \\
Indonesian.
\end{tabular} & $\begin{array}{c}\text { Indonesian } \\
\text { language and } \\
\text { literature will be } \\
\text { forgotten and } \\
\text { disappear } \\
\text { sooner or later. }\end{array}$ \\
\hline
\end{tabular}

The survey ended with 30 respondents from the third-semester English department students of Airlangga University 2021/2022 academic year, which were collected via Google Form.

As seen from Table 2, $40 \%$ of the respondents (12 students) said that they want to learn the language and culture of anime. While $46.7 \%$ of the respondents (14 students) answered probably, $10 \%$ of the respondents (3 students) answered that they had not decided, and 3.3\% of the respondents (one student) said that they don't want to learn the language and culture of anime. There were $53.3 \%$ of respondents, totaling 16 students, who answered that they were interested in exploring other Japanese literary works besides anime, $16.7 \%$ of respondents, totaling 5 students, answered not really, $23.3 \%$ of the respondents, which were 7 students, answered that they were not interested but still enjoyed it, and $6.7 \%$ or 2 other students answered that they are not interested at all. Furthermore, $60 \%$ of the respondents (18 students) said that anime could affect students' interest in the Indonesian language and literature, $26.7 \%$ of the respondents (8 students) answered that anime does not really affect the Indonesian language and literature, and 13.3\% of the respondents (4 students) answered that anime has no effect to their interest in the Indonesian language and literature.

Further data collection was carried out through interviews with several students who based on their survey answers, had a high interest in learning Japanese and deepened their knowledge about other Japanese literary works besides anime.

The authors interviewed 6 students and the results are presented in Table 3. 5 out of 6 students admitted that anime influences the use and desire to preserve Indonesian literature and language, while one student did not feel any significant influence. All of them believe that the Indonesian language and literature will become popular throughout the world and can compete with languages and literature from other countries. Next, from the case study problem that had been given, 2 students chose to ignore the maniac, one student chose to guide the maniac to know more about the Indonesian language and literature, and the 
other did not agree with the maniac's behavior. 3 out of 6 students think that the Indonesian language and literary works will eventually be lost and forgotten, one student said that the identity of the Indonesian nation would be lost, one student said that the Indonesian identity would be lost as well as the people's ability to speak Indonesian would decrease, and the rest thought that the people's ability to speak Indonesian would decrease and Indonesian literary works can be taken over by other countries.

\section{DISCUSSION}

\section{Anime motivates students to learn the language and culture in it}

From the results above, it can be concluded that the theory which states that anime has an influence on one's motivation in learning the language and culture in it is true. The theory put forward by Toyoshima (2013) regarding the "virtuous cycle", as well as previous research conducted by Rahma (2019), has proven to be still relevant today. Most students of English language and literature admitted that after watching anime, they had an interest in learning the language and culture. This then refers to the desire to explore more about other Japanese literary works such as songs, poems, and others.

\section{The negative impact that may be obtained from watching anime}

Overdoing an activity will definitely cause an impact. The impacts that will arise will also vary, whether it is beneficial or detrimental. Everything depends again on the person herself/himself. This also applies to watching anime.

Most students of English language and literature said that anime had an impact on the existence of the Indonesian language and literary works. They are well aware that anime contains Japanese elements which could threaten the existence and interest in studying and preserving the Indonesian language and literature, especially if someone is watching anime continuously. The national identity that exists in a person can also be replaced by the desire to become 'a Japanese' due to excessive liking for the Japanese language and culture brought by anime. Not only that, if interest in studying and preserving the Indonesian language and literary works wanes, then the language and literary works will slowly disappear and be forgotten. Indonesian literary works can also be filled with elements from the language and culture of other countries. The fading of the community's ability to speak Indonesian in the future is also inevitable.

\section{Student responses in preserving the Indonesian language and literature}

Based on the interviews' results, it can be concluded that English language and literature students are still well aware of the importance of preserving the Indonesian language and literature. They believe 
that with the significant development of technology and creativity of the younger generations, in the future, fascinating Indonesian literary works and the unique Indonesian language can spread all over the world. However, it depends on the Indonesian, this cannot be achieved if the appreciation of the Indonesian language and literary works in the country itself is lacking.

\section{How to overcome the negative impact that anime could bring}

There are two efforts that can be made to overcome the adverse effects of an activity. Those are efforts to prevent something from happening, and efforts to overcome what has happened.

To prevent the negative impacts of anime, parents should represent themselves with the basics of manga and anime to guide their children to age-appropriate films or comics. The appropriateness of their children's movies is based on what the parents are able to sort out. In addition, parents also need to manage time and content before showing it to their children. Children should not watch a show or movie that contains violence, pornography, and horror. If you are unable to identify which films are not appropriate to be watched, it is highly suggested to consult your parents before watching. It is a good way for you to protect yourself. Moreover, parents need to watch the development of their children by understanding their hobbies and environment. Parents are expected to guide their children's hobbies into lucrative ways, like drawing, making animation, and so on.

While, if the impacts have already happened, then students should reduce consuming anime, find another hobby, increase their socialization through friends or someone else, and go outside, not just stay at your home. Adolescents are expected to retain and increase their control of themselves as much possible as they can to develop their selective behavior or demeanor in following the lifestyle as anime fans.

\section{CONCLUSION}

To sum up, based on the results and discussions above, anime does affect the interest of English language and literature students at Airlangga University in studying the Japanese language and literature. Anime motivates them to study Japanese, as well as explore other works of Japanese literature. However, it cannot be denied that anime can also have a negative impact on the existence of the Indonesian language and literary works. These negative influences are the decreased interest in studying and preserving Indonesian language and literary works, fading of the nation's national identity within a person, the disappearance of Indonesian language and literary works, Indonesian literary works which are increasingly filled with elements of language and culture of other countries, as well as the declining ability of the people in the future to speak Indonesian. Students of the English language and literature also still have an awareness 
of the importance of preserving the Indonesian language and literary works. To prevent negative impacts anime affected, the efforts as a precaution are including parents should guide and direct their children from the beginning from a show or movie that they will give to their children, so children are able to conduct their hobbies through a right way. While efforts can be made if it is already affected, such as reducing their consumption of anime, finding another hobby, increasing socialization through friends or someone else, and not just staying at home. So children can develop their selective demeanor or behavior in order to follow the lifestyle as anime fans. Due to the pandemic, the data collection process was carried out online via Google Forms and WhatsApp. Therefore, the data obtained is not as good as the data collected face-to-face.

\section{REFERENCES}

1. Anjan, S.P., Astiti, D.P. Hubungan kontrol diri dan konformitas terhadap perilaku konsumtif remaja penggemar animasi Jepang (anime) di Denpasar. Jurnal Psikologi Udayana. 2020;(1)144-155

2. Bahri, M.A.S., Rochman, H.M. Diplomasi Budaya Anime Sebagai Soft-Power Jepang Guna Membangun Citra Positif Negara. Global and Policy Journal of International Relations. 2020;8(3)107118

3. Fadli, M.R. Memahami desain metode penelitian kualitatif. HUMANIKA: Kajian Ilmiah Mata Kuliah Umum. 2021;21(1)33-54

4. Firmansyah, M., Masrun, Yudha, I.D.K. Esensi Perbedaan Metode Kualitatif dan Kuantitatif. Elastisitas: Jurnal Ekonomi Pembangunan. 2021;3(2)156-159

5. Lafamane, F. Karya Sastra (Puisi, Prosa Drama). Jurnal Pendidikan Bahasa dan Sastra Indonesia. 2020

6. Rahmah, Y. Minat dan Motivasi Belajar Bahasa Jepang. Kiryoku. 2019;3(1)1-7

7. Suhandra, I.R. Hubungan Bahasa, Sastra, dan Ideologi. Cordova Journal: language and culture studies. 2019;9(2)172-182

8. Sebayang, E. Mempertahankan Identitas Nasional di Era Digital. RANGKIANG: Jurnal Pengabdian Pada Masyarakat. 2020;1(2)107-110

9. Sari, S. Literasi Media pada Generasi Milenial di Era Digital. Profesional: Jurnal Komunikasi dan Administrasi Publik. 2019;6(2)30-42

10. Wahidati, L., Kharismawati, M., Mahendra, A.O. Pengaruh Konsumsi Anime dan Manga Terhadap Pembelajaran Budaya dan Bahasa Jepang. Izumi. 2018;7(1)1-10

11. Wisanggeni, W.P. Soft Power Jepang di dalam Anime Samurai Champloo Sebagai Bentuk Diplomasi Kebudayaan. Jurnal Lugas. 2019;3(2)64-72

12. Yamane, T. Kepopuleran dan Penerimaan Anime Jepang di Indonesia. Ayumi: Jurnal Budaya, Bahasa dan Sastra. 2020;7(1)68-82 